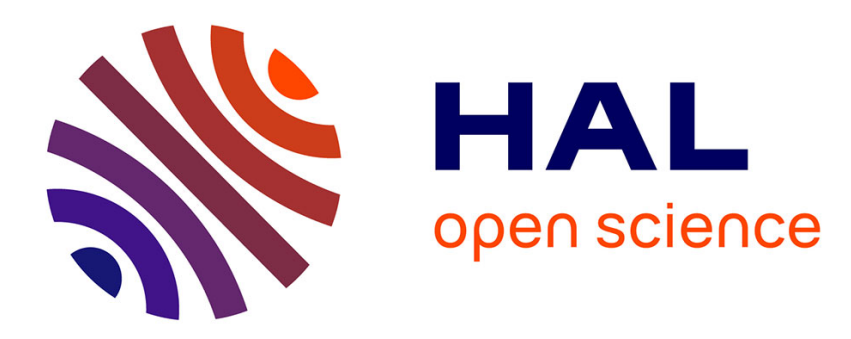

\title{
Atmospheric nitrogen deposition to the mullica river-great bay estuary
}

Jennifer Ayars, Yuan Gao

\section{To cite this version:}

Jennifer Ayars, Yuan Gao. Atmospheric nitrogen deposition to the mullica river-great bay estuary. Marine Environmental Research, 2007, 64 (5), pp.590. 10.1016/j.marenvres.2007.06.004 . hal00562985

\section{HAL Id: hal-00562985 \\ https://hal.science/hal-00562985}

Submitted on 4 Feb 2011

HAL is a multi-disciplinary open access archive for the deposit and dissemination of scientific research documents, whether they are published or not. The documents may come from teaching and research institutions in France or abroad, or from public or private research centers.
L'archive ouverte pluridisciplinaire HAL, est destinée au dépôt et à la diffusion de documents scientifiques de niveau recherche, publiés ou non, émanant des établissements d'enseignement et de recherche français ou étrangers, des laboratoires publics ou privés. 


\section{Accepted Manuscript}

Atmospheric nitrogen deposition to the mullica river-great bay estuary

Jennifer Ayars, Yuan Gao

PII:

S0141-1136(07)00075-X

DOI:

10.1016/j.marenvres.2007.06.004

Reference:

MERE 3128

To appear in:

Marine Environmental Research

Received Date:

16 May 2006

Accepted Date:

10 June 2007

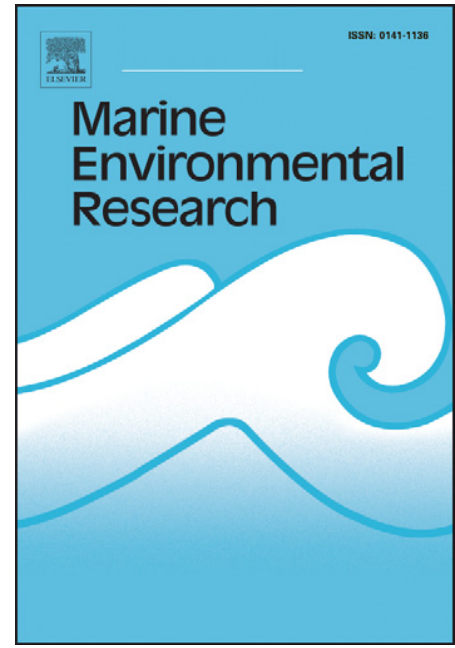

Please cite this article as: Ayars, J., Gao, Y., Atmospheric nitrogen deposition to the mullica river-great bay estuary, Marine Environmental Research (2007), doi: 10.1016/j.marenvres.2007.06.004

This is a PDF file of an unedited manuscript that has been accepted for publication. As a service to our customers we are providing this early version of the manuscript. The manuscript will undergo copyediting, typesetting, and review of the resulting proof before it is published in its final form. Please note that during the production process errors may be discovered which could affect the content, and all legal disclaimers that apply to the journal pertain. 


\title{
ATMOSPHERIC NITROGEN DEPOSITION TO THE MULLICA RIVER-GREAT BAY ESTUARY
}

\author{
Jennifer Ayars ${ }^{1}$ and Yuan $\mathrm{Gao}^{2 *}$
}

${ }^{1}$ Dresdner Robin

371 Warren Street, Jersey City, NJ 07302

E-mail: jhaa6027@yahoo.com

Tel.: 201-217-9200; fax: 201-217-9607

${ }^{2}$ Department of Earth and Environmental Sciences

Rutgers University

Newark, NJ 07102

E-mail: yuangaoh@andromeda.rutgers.edu

Tel.: 973-353-1139; Fax: 973-353-1965

${ }^{*}$ Corresponding author

Manuscript for Marine Environmental Research

April 2007 


\begin{abstract}
Measurements of nitrate and ammonium in precipitation and associated with aerosols were conducted at Rutgers University Marine Field Station in Tuckerton, New Jersey from March 2004 to March 2005 to characterize atmospheric nitrogen deposition to the Mullica River-Great Bay Estuary. The arithmetic means of nitrate and ammonium concentrations for precipitation samples were $2.3 \mathrm{mg} \mathrm{L}^{-1}$ and $0.42 \mathrm{mg} \mathrm{L}^{-1}$, respectively. Nitrate and ammonium concentrations in aerosol samples averaged $3.7 \mu \mathrm{g} \mathrm{m}^{-3}$ and $1.6 \mu \mathrm{g}$ $\mathrm{m}^{-3}$, respectively. Wet deposition rates appeared to vary with season; the highest rate of inorganic nitrogen deposition (nitrate + ammonium) occurred in the spring with an average value of $1.33 \mathrm{~kg}-\mathrm{N} \mathrm{ha}{ }^{-2}$ month $^{-1}$. On an annual basis, the total (wet and dry) direct atmospheric deposition fluxes into the Mullica River-Great Bay Estuary were 7.08 $\mathrm{kg}-\mathrm{N} \mathrm{ha}{ }^{-2} \mathrm{yr}^{-1}$ for nitrate and $4.44 \mathrm{~kg}-\mathrm{N} \mathrm{ha} \mathrm{yr}^{-1}$ for ammonium. The total atmospheric inorganic nitrogen directly deposited to the Mullica River-Great Bay Estuary was estimated to be $4.79 \times 10^{4} \mathrm{~kg}-\mathrm{N} \mathrm{yr}^{-1}$, and the total atmospheric inorganic nitrogen deposited to the Mullica River watershed was estimated to be $1.69 \times 10^{6} \mathrm{~kg}^{-\mathrm{N} \mathrm{yr}^{-1}}$. Only a fraction of the nitrogen deposited on the watershed will actually reach the estuary; most of the nitrogen will be retained in the watershed due to utilization and denitrifaction during transport. The amount of $\mathrm{N}$ reaching the Mullica River-Great Bay Estuary indirectly is estimated to be $5.07 \times 10^{4} \mathrm{~kg}-\mathrm{N}$ year ${ }^{-1}$, approximately $97 \%$ is retained within the watershed. This atmospheric nitrogen deposition may stimulate phytoplankton productivity in the Mullica River-Great Bay ecosystem.
\end{abstract}

Keywords: nitrogen compounds, atmospheric nitrate and ammonium, deposition rate, coastal waters, eutrophication. 


\section{Introduction}

An important portion of nitrogen $(\mathrm{N})$ entering coastal waters is of atmospheric origin. Atmospheric nitrogen can reach coastal waters by direct deposition pathways: wet deposition by precipitation and dry deposition by both aerosol particles and gases, and it can also enter the coastal waters by indirect pathways through deposition first to the land surface and then subsequent runoff. Studies conducted along the east coast of the United States indicate that atmospheric nitrogen deposition represents a significant amount of the total nitrogen input to coastal waters (Fisher and Oppenheimer, 1991; Paerl and Fogel, 1994; Russell et al, 1998; Scudlark et al., 1998; Castro and Driscoll, 2002; Whitall et al., 2003). A large fraction of the atmospheric nitrogen input is in the form of inorganic nitrogen, mainly nitrate $\left(\mathrm{NO}_{3}{ }^{-}\right)$and ammonium $\left(\mathrm{NH}_{4}{ }^{+}\right) . \mathrm{NO}_{3}{ }^{-}$is formed through atmospheric reactions involving $\mathrm{NO}_{\mathrm{x}}$, and emission sources for $\mathrm{NO}_{\mathrm{x}}$ include fossil fuel combustion from automobiles and industries, biomass burning, and other natural fixation processes. The formation of $\mathrm{NH}_{4}{ }^{+}$is mainly by the gas-to-particle conversion reactions of $\mathrm{NH}_{3}$ in the atmosphere, and $\mathrm{NH}_{3}$ is primarily derived from agricultural waste, fertilizers, industrial emissions, and decomposition of organic substances (Seinfeld and Pandis, 1998; Paerl, 2002).

Organic $\mathrm{N}$ can also contribute to a sizeable portion of the total wet deposition budget (Cornell et al., 1995; Whitall et al. 2003). Recent measurements for coastal North Carolina indicated that $\sim 30 \%$ of the total $\mathrm{N}$ in rainwater was organic $\mathrm{N}$ (Peierls and Paerl, 1997). Although sources of organic nitrogen in the atmosphere are not well understood, certain contributions to atmospheric organic nitrogen from natural sources such as sea spray droplets and plant pollens have been noted (Prospero et al., 1996). Another 
important component in the total atmospheric deposition could be dry deposition by gasphase nitrogen which has not been studied widely and is often omitted from calculations of the total $\mathrm{N}$ deposition. Recent studies from coastal New Jersey and North Carolina indicate that both oxidized $\mathrm{N}$ such as $\mathrm{HNO}_{3}$ and reduced $\mathrm{N}$ such as $\mathrm{NH}_{3}$ contribute significantly to the dry deposition of atmospheric nitrogen (CASTNET; Walker et al., 2004). Therefore, careful considerations of the contributions of these gas-phase $\mathrm{N}$ species to the dry deposition, as well as organic $\mathrm{N}$, should be incorporated into future atmospheric $\mathrm{N}$ measurements.

Nitrogen is a major nutrient that controls primary productivity in many coastal waters, and atmospheric deposition is an important non-point source of both organic and inorganic nitrogen (Ryther and Dunstan, 1971; Vitousek and Howarth, 1991; Nixon, 1995; Paerl, 1995; Paerl and Whitall, 1999; Seitzinger and Sanders, 1999; Rabalais, 2002; Driscoll et al., 2003; Galloway et al., 2003). Excessive fluxes of nitrogen from atmospheric sources result in the eutrophication of many coastal waters in the United States, which is now considered the most widespread water quality problem (Nixon, 1995; Carpenter et al., 1998).

This work focuses on the Mullica River-Great Bay Estuary to characterize the atmospheric inorganic nitrogen $\left(\mathrm{NO}_{3}{ }^{-}\right.$and $\left.\mathrm{NH}_{4}{ }^{+}\right)$input from precipitation and associated with aerosols. The Mullica River-Great Bay Estuary is located along the southern New Jersey coastline, approximately 14 kilometers north of Atlantic City. It extends from Lower Bank (freshwater/saltwater interface) in the Mullica River to Little Egg Inlet (polyhaline) and consists primarily of open estuary bordered by salt marshes (Kennish et al., 2004). The waters in this region have traditionally been undisturbed and clean with 
little human impact. Most of the Mullica River watershed is sheltered from anthropogenic input because the upstream portions are part of the New Jersey Pinelands National Reserve, while the downstream portions are surrounded by federal and state wildlife refuges (Psuty et al., 1993; Zampella et al., 2001). This estuary, therefore, can serve as an excellent reference location to assess the health of impacted coastal ecosystems in New Jersey. To date, there has been little data collected to evaluate atmospheric nitrogen deposition to this ecosystem.

\section{Methods}

\subsection{Sampling Collection}

Atmospheric precipitation and aerosol samples were collected at Rutgers University Marine Field Station (RUMFS) in Tuckerton, New Jersey $\left(39.59^{\circ} \mathrm{N}, 74.34^{\circ}\right.$ W) from March 2004 to March 2005. This site is located at the southern tip of a salt marsh peninsula across from the Little Egg Inlet in the Mullica River-Great Bay Estuary (Figure 1). Precipitation samples were collected by a MIC wet-only automatic precipitation sampler controlled by an onsite rain sensor (MIC Company, Richmond, Ontario, Canada). A total of 51 precipitation samples were collected on an event-basis throughout the year, using plastic reservoir sets that were previously cleaned and sealed in plastic bags until use. A precipitation event during this study was arbitrarily defined as the collection of small amounts of precipitation over a raining period that could last for a consecutive three to four days or one day of heavy precipitation. The annual precipitation rate during this study period was $107.5 \mathrm{~cm}$ and the average precipitation rate was $8.99 \mathrm{~cm} /$ month. After the precipitation sample was collected, the bottle with the 
unfiltered sample was labeled. A total of 22 aerosol samples were also collected using a Model 500EL high-volume aerosol sampler with a flow rate of $\sim 1 \mathrm{~m}^{3} \mathrm{~min}^{-1}$ (Aquaero Tech, Miami, Florida, USA). Whatman 41 and 48 cellulose filter papers (both with the same filtration efficiency of air particulate matter but different ash maximum) were used to collect the samples, and the sampling duration lasted between 6 and 24 hours. On average, two samples were collected per week from March 2004 to May 2004. After collection, the sample filter was unloaded, placed in a plastic bag and labeled. All samples were stored frozen until analysis.

\subsection{Chemical Analysis}

To prepare precipitation samples for analysis, the frozen samples were first thawed at room temperature. The $\mathrm{pH}$ of each sample was determined with a SevenEasy $\mathrm{pH}$ meter (Mettler Toledo, Germany). Each sample was subsequently filtered to remove particulate matter using a polycarbonate filter of $0.45 \mu \mathrm{m}$ pore size along with a $250 \mathrm{ml}$ Nalgene filtration system. To prepare aerosol samples for analysis, one-fourth of each sample filter was leached in $100 \mathrm{ml}$ deionized water ultrasonically for $\sim 1$ hour. Then the samples were filtered following the same procedure as that used for precipitation sample preparation. The details of the method can be found in Gao et al. (1996). The analysis of nitrate and ammonium in precipitation and aerosols was conducted at Montclair State University (MSU) with a Dionex 2500 Ion Chromatograph (IC) (Dionex Corporation). The 2500 IC system was equipped with an IonPac AG11-HC 4mm guard column and an IonPac AS18 4mm analytical column for anions such as nitrate. An eluent mixture of $50 \%$ w/w sodium hydroxide $(\mathrm{NaOH})$ and distilled water was used to elute nitrate and the

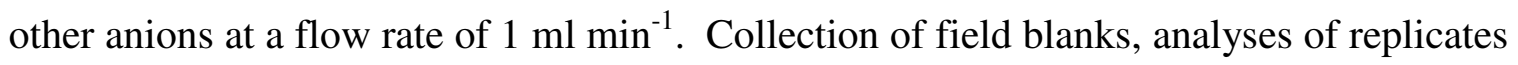


and an interlaboratory comparison were conducted to assure the data quality. The IC detection limits were $0.05 \mathrm{mg} \mathrm{L}^{-1}$ for nitrate and $0.05 \mathrm{mg} \mathrm{L}^{-1}$ for ammonium. As a data QA/QC procedure, a total of five precipitation samples that were analyzed at MSU were also analyzed at a lab at Rutgers University Pineland Field Station in New Jersey, and the concentrations from the two labs agreed within 15\%, although the samples were stored longer at the Pineland Field Station before analysis. Therefore, the different storage times could be a contributing factor to the difference in concentrations as a result of a chemical change in composition over time. There could also be a difference in results due to the age of each of the laboratory's IC's column and suppressor as well as different standard operating procedures and quality assurance practices procedures established at different laboratories.

\section{Results and Discussion}

\subsection{Nitrate and Ammonium Concentrations in Precipitation and Aerosols}

Figure 2 shows the concentrations of nitrate and ammonium in precipitation. The nitrate concentrations for precipitation were always higher than ammonium concentrations. The arithmetic means of nitrate and ammonium concentrations in precipitation were $2.3 \mathrm{mg} \mathrm{L}^{-1}$ and $0.42 \mathrm{mg} \mathrm{L}^{-1}$, respectively. These results are comparable to other studies conducted along the east coast (Russell et al., 1998; Gao, 2002). Gao (2002) found that the average nitrate concentration for precipitation was 1.8 $\mathrm{mg} \mathrm{L}^{-1}$, and the average ammonium concentration was $0.33 \mathrm{mg} \mathrm{L}^{-1}$ for Barnegat Bay, New Jersey. At Edwin B. Forsythe National Wildlife Refuge located in Atlantic County,

New Jersey, the annual mean concentration in precipitation was $0.88 \mathrm{mg} \mathrm{L}^{-1}$ for nitrate, 
and $0.20 \mathrm{mg} \mathrm{L}^{-1}$ for ammonium in 2005 , and in 2004 , the nitrate and ammonium concentrations were $1.00 \mathrm{mg} \mathrm{L}^{-1}$ and $0.15 \mathrm{mg} \mathrm{L}^{-1}$, respectively. The eight-year precipitation record (1988-2005) shows the average concentrations of $0.99 \mathrm{mg} \mathrm{L}^{-1}$ for nitrate and $0.16 \mathrm{mg} \mathrm{L}^{-1}$ for ammonium at this location (NADP/NTN). At Washington Crossing in Mercer County in New Jersey, the annual concentrations of nitrate and ammonium in precipitation were $1.53 \mathrm{mg} \mathrm{L}^{-1}$ for nitrate and $0.30 \mathrm{mg} \mathrm{L}^{-1}$ for ammonium in 2004 and $1.04 \mathrm{mg} \mathrm{L}^{-1}$ for nitrate and $0.21 \mathrm{mg} \mathrm{L}^{-1}$ for ammonium in 2005 (NADP/NTN). At the Chesapeake Bay, the volume-weighted average concentrations of nitrate and ammonium from wet deposition were 1.3 and $0.24 \mathrm{mg} \mathrm{L}^{-1}$, respectively (Russell et al., 1998). It is worth noting that there were variations in the average nitrate and ammonium concentrations for the above studies, and there are many factors contributing to the concentration differences, such as the sampling locations, the strength of emission sources, the year of the study, and the precipitation rates.

The values for nitrate and ammonium concentrations in aerosol samples for the spring are shown in Figure 3. The average nitrate and ammonium concentrations were $3.7 \mu \mathrm{g} \mathrm{m}^{-3}$ and $1.6 \mu \mathrm{g} \mathrm{m}^{-3}$, respectively. Nitrate concentrations in the aerosol samples were higher than ammonium concentrations in this area. At Barnegat Bay, New Jersey, the nitrate concentrations in aerosol observed during a recent two-year measurement were also higher than ammonium concentrations, with average concentrations of $2.0 \pm 0.89 \mu \mathrm{g}$ $\mathrm{m}^{-3}$ for nitrate and $0.50 \pm 0.28 \mu \mathrm{g} \mathrm{m}^{-3}$ for ammonium (Gao, 2002). However, at Washington Crossing, an inland location in New Jersey, the average concentration of aerosol nitrate in 2004 was $1.2 \mu \mathrm{g} \mathrm{m}^{-3}$, slightly lower than that for aerosol ammonium $\left(1.5 \mu \mathrm{g} \mathrm{m}^{-3}\right)$, and the six-year (2000-2005) average concentrations for aerosol nitrate and 
ammonium at this location show the same feature (CASTNET). This feature also exists at other locations in the eastern United States. At Abington, Connecticut, the average aerosol concentrations for the period of $2000-2005$ were $0.84 \mu \mathrm{g} \mathrm{m}^{-3}$ for nitrate and 1.1 $\mu \mathrm{g} \mathrm{m}^{-3}$ for ammonium, and at Blackwater, Maryland for the same period, the average concentrations for aerosol nitrate and ammonium were $1.3 \mu \mathrm{g} \mathrm{m} \mathrm{m}^{-3}$ and $1.7 \mu \mathrm{g} \mathrm{m}^{-3}$, respectively (CASTNET). The higher concentration of aerosol nitrate observed at coastal New Jersey may be attributed to a contribution of sea-salt nitrate in addition to nitrate from non-marine sources. A comparison table of the above studies conducted along the east coast is included in Table 1.

The average value of the $\mathrm{pH}$ in all precipitation samples was 4.32 , with a range of 3.65 to 5.05 , indicating the acidic nature in precipitation at this location. The cause of this acidity is likely anthropogenic emissions from the combustion of fossil fuels which release nitrogen oxides and sulfur dioxide into the atmosphere. These gas pollutants are the primary sources for acid deposition because they are later transformed into nitric and sulfuric acids which increase the acidity of precipitation (Seinfeld and Pandis, 1998). Figure 4 demonstrates a negative correlation between $\mathrm{pH}$ and nitrate and ammonium concentrations in precipitation: high nitrate and ammonium concentrations were related to low $\mathrm{pH}$ values. Acidic rainfall combined with high inorganic nitrogen concentrations could increase primary productivity when compared to more neutral rain (Paerl, 1985).

\subsection{Atmospheric Flux Calculations}

Based on the in situ measurements of nitrate and ammonium, the atmospheric flux via wet and dry deposition can be calculated using wet and dry deposition models for the Mullica River-Great Bay Estuary. Wet deposition involves the removal of atmospheric 
substances within clouds and below the cloud base mainly by precipitation (Pryor and Barthelmie, 2000). The wet deposition flux $\left(\mathrm{F}_{\mathrm{w}}\right)\left(\mathrm{mg} \mathrm{m}^{-2} \mathrm{month}^{-1}\right)$ can be calculated by the following equation:

$$
\mathrm{F}_{\mathrm{w}}=10 \mathrm{C}_{\mathrm{r}} * \mathrm{P}
$$

where $C_{r}$ is the concentration of nitrate or ammonium in precipitation $\left(\mathrm{mg} \mathrm{L}^{-1}\right), \mathrm{P}$ is the precipitation rate $\left(\mathrm{cm} \mathrm{month}^{-1}\right)$, and 10 is a unit conversion factor. Dry deposition can be defined as the removal of gaseous and particulate species from the atmosphere without precipitation. Gas diffusion, impaction, and gravitational settling play a role in the dry deposition of particles. The particle dry deposition process depends primarily on the

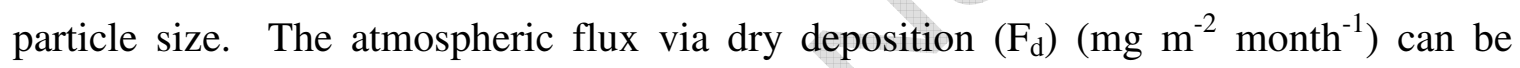
calculated by the following equation:

$$
\mathrm{F}_{\mathrm{d}}=\left(2.592 \times 10^{4}\right) * \mathrm{C}_{\mathrm{air}} * \mathrm{~V}_{\mathrm{d}}
$$

where $C_{a i r}$ is the concentration of nitrate or ammonium in the air $\left(\mathrm{mg} \mathrm{m}^{-3}\right), V_{d}$ is the dry deposition velocity $\left(\mathrm{cm} \mathrm{s}^{-1}\right)$, and $2.592 \times 10^{4}$ is a unit conversion factor. The average dry deposition velocities are assumed to be $0.34 \mathrm{~cm} \mathrm{~s}^{-1}$ for aerosol nitrate and $0.19 \mathrm{~cm} \mathrm{~s}^{-1}$ for aerosol ammonium. These values were derived based on in situ measurements of three sets of aerosol particle-size distributions with a cascade impactor sampler at the same location conducted in an earlier study (Gao, 2002); therefore, these $\mathrm{V}_{\mathrm{d}}$ values are consistent for the same geographical area, and this could limit uncertainty. On the other hand, due to a number of environmental factors (wind speed and direction, solar radiation, air temperature, relative humidity, etc.), which constantly change from time to time even within the same area, the use of the above $V_{d}$ values could involve substantial uncertainties. For this reason, we adopted the $\pm 50 \%$ uncertainty associated with the 
average values assumed by Gao (2002). We acknowledge that higher uncertainty levels with a range of $0.001-2 \mathrm{~cm} \mathrm{~s}^{-1}$ are possible as suggested by other researchers (Slinn and Slinn, 1980; Williams, 1982; Clark and Kremer, 2005). These deposition velocities were previously used within the same study region. There are uncertainties associated with the values of dry deposition velocity and these values can only serve as first approximations.

\subsection{Seasonal Patterns of Atmospheric Nitrogen Deposition}

Total wet deposition (nitrate + ammonium) appeared to be highest in the spring for the Mullica River-Great Bay Estuary, with the average rate being $1.33 \mathrm{~kg}-\mathrm{N} \mathrm{ha}{ }^{-2}$ month $^{-1}$, which accounts for approximately $41 \%$ of the total wet deposition (Figure 5a). Total dry deposition appeared to increase from March to May 2004: $0.089 \mathrm{~kg}-\mathrm{N} \mathrm{ha}{ }^{-2}$ month $^{-1}$ for March, $0.118 \mathrm{~kg}-\mathrm{N} \mathrm{ha}{ }^{-2}$ month $^{-1}$ for April, and $0.177 \mathrm{~kg}-\mathrm{N} \mathrm{ha}{ }^{-2}$ month $^{-1}$ for May, approximately a 20-30\% increase per month (Figure 5b). However, this study could not determine the seasonal variation in dry deposition at this location due to limited aerosol sampling. The preliminary results suggest that the formation of nitrate and ammonium in the atmosphere could be promoted by increased air temperature and solar radiation intensity. Many studies have found that atmospherically deposited nitrogen varies seasonally, with the highest concentrations and deposition fluxes occurring during the warmer seasons (Russell, et al., 1998; Gao, 2002; Luo et al., 2002; Sheeder et al., 2002; Whitall et al., 2003). These seasonal patterns may be the result of a seasonal variation in the precipitation rates and the emission of nitrogen species into the atmosphere (Gao, 2002; Sheeder et al., 2002). The direction from which an air mass originates can also affect the deposition of nitrogen species. Meteorological parameters during the measurement period of this study indicate that a high atmospheric nitrogen 
deposition event is usually associated with the air masses having an inland origin, and vise versa, consistent with many previous observations (Prospero et al., 1996; Whitall et al., 2003; Butler et al., 2005; Clark and Kremer, 2005).

\subsection{Annual Atmospheric Nitrogen Deposition}

Based on the average monthly deposition rates, the annual wet deposition fluxes for nitrate and ammonium were estimated to be $6.21 \mathrm{~kg}-\mathrm{N}$ ha ${ }^{-2}$ year $^{-1}$ and $3.77 \mathrm{~kg}-\mathrm{N} \mathrm{ha}{ }^{-2}$ year $^{-1}$, respectively, for the Mullica River-Great Bay Estuary. The dry deposition flux for this same region was estimated to be $0.219 \mathrm{~kg}-\mathrm{N} \mathrm{ha}^{-2}$ month $^{-1}$ for nitrate and $0.169 \mathrm{~kg}-\mathrm{N}$ $\mathrm{ha}^{-2}$ month $^{-1}$ for ammonium. However, the dry deposition flux values only reflect the dry deposition of nitrogen for the spring due to the limited aerosol sampling. Assuming that there is no seasonal change for the remainder of the year, the annual dry deposition was roughly estimated to be $0.874 \mathrm{~kg}-\mathrm{N} \mathrm{ha}{ }^{-2}$ year $^{-1}$ for nitrate and $0.670 \mathrm{~kg}-\mathrm{N} \mathrm{ha}{ }^{-2}$ year $^{-1}$ for ammonium. These estimates may involve certain degrees of uncertainties since the dry deposition was not directly measured for the entire year and it is likely to change with season.

The above results are comparable to other studies (Table 2). At Washington Crossing in Mercer County, New Jersey, annual wet deposition of nitrate and ammonium was estimated to be $4.0 \mathrm{~kg}-\mathrm{N}$ ha $^{-2}$ year $^{-1}$ and $3.23 \mathrm{~kg}-\mathrm{N}$ ha $^{-2}$ year $^{-1}$, respectively, in 2004. Annual dry deposition was estimated to be $0.1 \mathrm{~kg} \mathrm{~N} \mathrm{ha}^{-2}$ year $^{-1}$ for nitrate and $0.5 \mathrm{~kg} \mathrm{~N}$ $\mathrm{ha}^{-2}$ year $^{-1}$ for ammonium during the same year (CASTNET/NADP-NTN). In 2005 at Edwin B. Forsythe National Wildlife Refuge located in Atlantic County, New Jersey, annual wet deposition of nitrate and ammonium was estimated to be $9.83 \mathrm{~kg} \mathrm{~N} \mathrm{ha}^{-2}$ 
year $^{-1}$ and $2.22 \mathrm{~kg} \mathrm{~N} \mathrm{ha}^{-2}$ year $^{-1}$, respectively (NADP/NTN). Annual dry deposition values were not available for this site.

Based on the above calculations, the total annual atmospheric deposition flux for nitrate was then calculated to be $7.08 \mathrm{~kg} \mathrm{ha}^{-2}$ year $^{-1}$ and $4.44 \mathrm{~kg} \mathrm{ha}^{-2}$ year $^{-1}$ for ammonium to the Mullica River-Great Bay Estuary. Nitrate deposition accounts for $\sim 61 \%$ of the total inorganic nitrogen deposition to this estuary (Table 3). The surface area of the Mullica River-Great Bay Estuary is 4,160 ha (41.6 km²) (Kennish et al., 2004). Consequently, the total atmospheric nitrate and ammonium directly deposited to this estuary is estimated to be $4.79 \times 10^{4} \mathrm{~kg} \mathrm{~N}_{\text {year }}{ }^{-1}$. An estimate of the total atmospheric nitrate and ammonium deposited to the Mullica River's watershed is determined to be $1.69 \times 10^{6} \mathrm{~kg} \mathrm{~N} \mathrm{year}^{-1}$, based on the area of the watershed (147,500 ha) (Zampella et al., 2001).

It is worth noting that the annual deposition estimates of atmospheric nitrate and ammonium from this study represents the atmospheric deposition for a specific year only (March 2004-March 2005). Due to the changes in precipitation rates, air pollution emission rates, etc. from year to year, interannual variability in deposition likely exists in this area. A recent two-year measurement of atmospheric nitrate and ammonium within the same region (Gao, 2002) shows that the annual wet deposition decreased $\sim 2 \%$ for nitrate and almost $16 \%$ for ammonium from year one to year two. Therefore, it is necessary to establish a long-term record of atmospheric $\mathrm{N}$ deposition to a sensitive coastal ecosystem through multi-year atmospheric measurements.

Dissolved organic nitrogen (DON) in precipitation may contribute to the total atmospheric $\mathrm{N}$ deposition. Atmospheric DON has recently drawn increasing attention as 
a significant additional source of "new" $\mathrm{N}$ input to both coastal and oceanic regions (Cornell et al., 1995; Seitzinger and Sanders, 1999). Measurements from coastal North Carolina indicate that $30 \%$ of rainwater $\mathrm{N}$ concentrations and deposition occurred in organic form, and $20-30 \%$ of atmospheric organic $\mathrm{N}$ was available for the uptake by primary producers on short time scales (Peierls and Paerl, 1997). Studies conducted in Narragansett Bay, Rhode Island, show that $\sim 19 \% \mathrm{~N}$ in precipitation is organic $\mathrm{N}$ (Nixon et al., 1995). At Lewes, Delaware, organic $\mathrm{N}$ in precipitation accounts for $\sim 23 \%$ of the total N (Scudlark et al., 1998). Preliminary results obtained from the analysis of limited precipitation samples collected at Barnegat Bay show that DON accounts for $\sim 20 \%$ of the total dissolved $\mathrm{N}$ in precipitation in this area (Gao, unpublished data). Earlier studies conducted in the same region show that DON accounts for an important portion of the total atmospheric $\mathrm{N}$ deposition, $\sim 20 \%$ at New Brunswick and 7-12\% at Barnegat Bay in New Jersey (Seitzinger and Sanders, 1999). Clearly, DON in precipitation is an important component of the total atmospheric $\mathrm{N}$ over the coastal ocean. Due to the limited scope of this study, DON was not measured, and therefore the current estimate of total atmospheric wet deposition in this region, in particular bioavailable $\mathrm{N}$, may be

undervalued. Assuming that the portion of DON in wet deposition is the same as those mentioned above, the total atmospheric $\mathrm{N}$ fluxes by wet deposition from this study could be underestimated by $\sim 10-20 \%$.

\subsection{Contribution of Atmospheric Deposition to the Annual Nitrogen Input to the} Mullica River-Great Bay Estuary

All atmospheric nitrogen deposited directly to the Mullica River-Great Bay Estuary is available for use by primary producers. However, only a fraction of the 
nitrogen deposited on the watershed will actually reach the estuary. Most of the nitrogen will be retained in the watershed and/or utilized and denitrified during transport through the watershed. After utilizing a simple retention model outlined in Whitall et al. (2003) based on the land cover at the site, the amount of $\mathrm{N}$ actually reaching the Mullica RiverGreat Bay Estuary indirectly is estimated to be $5.07 \times 10^{4} \mathrm{~kg} \mathrm{~N}_{\text {year }}{ }^{-1}$, approximately $97 \%$ is retained within the watershed. This value is considered a rough estimate because an average retention value for generalized land use types was applied to the entire watershed. Parameters, such as soil $\mathrm{N}$ content, soil type, land slope, elevation and vegetative type, which are land parcel-specific, determine true nutrient detention values (Valigura et al, 1996, Whitall et al., 2003). At the Neuse River Estuary in North Carolina, approximately $94 \%$ of atmospheric $\mathrm{N}$ was retained in the watershed. The land cover that dominates in the watershed is forest, similar to the Mullica River-Great Bay Estuary (Whitall et al., 2003). In Waquoit Bay, Massachusetts, $89 \%$ of atmospheric $\mathrm{N}$ is lost within the watershed; approximately $10 \%$ reaches the estuary. In this area, urban land such as residential areas cover approximately $39 \%$ of the land, with natural vegetation only covering $21 \%$ (Valiela, et al., 1997).

The total amount of atmospheric inorganic nitrogen entering the Mullica RiverGreat Bay Estuary is $9.86 \times 10^{4} \mathrm{~kg} \mathrm{~N}_{\text {year }}{ }^{-1}$, approximately $49 \%$ is the result from direct deposition and $51 \%$ from indirect deposition. Considering the limited surface area of this estuary compared with that of the watershed (a ratio of 1:35), the direct deposition of atmospheric nitrogen certainly accounts for a large portion of the total input of this nutrient to the estuary. This atmospheric nitrogen deposition data will be extremely valuable in the development of an annual nitrogen budget for the estuary. 


\section{Conclusions}

Nitrogen is a major nutrient that controls primary productivity in many coastal waters, and atmospheric deposition is an important non-point source of both organic and inorganic nitrogen. This project was the first to quantify the atmospheric inorganic nitrogen (nitrate and ammonium) input to the Mullica River-Great Bay Estuary. The average concentrations of nitrate and ammonium in the precipitation samples were 2.3 $\mathrm{mg} \mathrm{L}^{-1}$ and $0.42 \mathrm{mg}, \mathrm{L}^{-1}$, respectively. The average aerosol concentrations were $3.7 \mu \mathrm{g}$ $\mathrm{m}^{-3}$ for nitrate and $1.6 \mu \mathrm{g} \mathrm{m}^{-3}$ for ammonium in the spring. Atmospheric wet deposition of nitrogen appeared to vary with season; the highest flux occurred during the spring, with an average value of $1.33 \mathrm{~kg}-\mathrm{N} \mathrm{ha}{ }^{-2}$ month $^{-1}$ accounting for approximately $41 \%$ of the total annual wet deposition. This seasonal deposition could be influenced by the variation in emission source strength, precipitation rate, and the origin of the air masses.

The total (wet + dry) annual atmospheric deposition fluxes were $7.08 \mathrm{~kg} \mathrm{~N} \mathrm{ha}^{-2}$ year $^{-1}$ for nitrate and $4.44 \mathrm{~kg} \mathrm{~N} \mathrm{ha}^{-2}$ year $^{-1}$ for ammonium. The total atmospheric inorganic nitrogen directly deposited to this estuary was estimated to be $4.79 \times 10^{4} \mathrm{~kg} \mathrm{~N}$ year $^{-1}$. The estimated deposition of $\mathrm{N}$ to the Mullica River watershed was $1.69 \times 10^{6} \mathrm{~kg}$ $\mathrm{N}$ year ${ }^{-1}$. Only $\sim 3 \%$ of the inorganic $\mathrm{N}$ deposited to the watershed ultimately reaches the estuary. The total amount of atmospheric inorganic nitrogen entering the Mullica RiverGreat Bay Estuary is $9.86 \times 10^{4} \mathrm{~kg} \mathrm{~N}_{\text {year }}{ }^{-1}$; approximately $49 \%$ is the result from direct deposition and 51\% from indirect deposition. High atmospheric nitrogen deposition may stimulate phytoplankton productivity in this coastal ecosystem. It is worth noting that these percentages are based on the calculations with nitrate and ammonium only. If gaseous $\mathrm{N}$ species and organic $\mathrm{N}$ were included, the values would likely change to some 
extent. Therefore, future fieldwork should include simultaneous measurements of gasphase $\mathrm{N}$ and organic $\mathrm{N}$ in addition to $\mathrm{N}$ in aerosol and precipitation phases, to improve the atmospheric $\mathrm{N}$ flux estimates.

\section{ACKNOWLEDGEMENTS:}

Special thanks to the staff at Rutgers University Marine Field Station for help with this research, especially Gregg Sakowicz for his help with precipitation sample collection and Roger Holden for equipment installation. Thanks to Michael Kennish for valuable comments and Dennis Gray for assistance with cation analysis. This research was supported by a graduate research fellowship from the Estuarine Reserves Division of National Oceanic and Atmospheric Administration Grant number NA04NOS4200135. 


\section{REFERENCES}

AIRMoN-dry network. NOAA ARL (National Oceanic and Atmospheric Administration Air Resource Laboratory).

Website http://www.arl.noaa.gov/research/projects/airmon_data.htm

Carpenter, S.R., Caraco, N.F., Correll, D.L., Howarth, R.W., Sharpley, A.N., \& Smith, V.H. (1998). Nonpoint pollution of surface waters with phosphorous and nitrogen. Ecological Applications, 8, 559-568.

CASTNET (Clean Air Status and Trend Network). U.S. Environmental Protection Agency: Washington Crossing, NJ.

Website http://www.epa.gov/castnet/

Castro, M.S., \& Driscoll, C.T. (2002). Atmospheric nitrogen deposition to estuaries in the mid-Atlantic and northeastern United States. Environmental Science and Technology, 36(15), 3242-3249.

Cornell, S., Rendell, A., \& Jickells, T. (1995). Atmospheric input of dissolved organic nitrogen to the oceans. Nature, 376, 243-246.

Draxler, R.R., \& Rolph, G.D. (2003). HYSPLIT (Hybrid Single-Particle Lagrangian Integrated Trajectory) Model. NOAA Air Resources Laboratory: Silver Spring, MD. Website http://www.arl.noaa.gov/ready/hysplit4.html

Driscoll, C.T., Whitall, D., Aber, J., Boyer, E., Castro, M., Cronan, C., Goodale, C.L., Groffman, P., Hopkinson, C., Lambert, K., Lawrence, G., \& Ollinger, S. (2003). Nitrogen pollution in the northeastern United States: sources, effects, and management options. BioScience, 53(4), 357-372.

Fisher, D.C., \& Oppenheimer, M. (1991). Atmospheric nitrogen deposition and the Chesapeake Bay estuary. Ambio, 23, 102-208.

Galloway, J.N., Aber, J.D., Erisman, J.W., Seitzinger, S.P., Howarth, R.W., Cowling, E.B., \& Cosby, B.J. (2003). The nitrogen cascade. BioScience, 53(4), 341-354.

Gao, Y., Arimoto, R., Duce, R.A., Chen, L.Q., Zhou, M.Y., \& Gu, D.Y. (1996). Atmospheric non-sea-salt sulfate, nitrate and methanesulfonate over the China Sea. Journal of Geophysical Research, 101, 12601-12611.

Gao, Y. (2002). Atmospheric nitrogen deposition to Barnegat Bay. Atmospheric Environment, 36, 5783-5794.

Kennish, M.J., Haag, S.M., Sakowicz, G.P., \& Durand, J.B. (2004). Benthic macrofaunal community structure along a well-defined salinity gradient in the Mullica RiverGreat Bay Estuary. Journal of Coastal Research, Special Issue 45, 209-226. 
Luo, Y., Yang, X., Carley, R.J., \& Perkins, C. (2002). Atmospheric deposition of nitrogen along the Connecticut coastline to Long Island Sound: a decade of measurements. Atmospheric Environment, 36, 4517-4528.

National Atmospheric Deposition Program/National Trends Network (NADP/NTN). NADP Program Office: Edwin B. Forsythe National Wildlife Refuge (NJ00), Atlantic County, NJ.

Website http://nadp.sws.uiuc.edu/sites/siteinfo.asp?met=MTM\&id=NJ00

Nixon, S.W. (1995). Coastal marine eutrophication: a definition, social causes, and future concerns. Ophelia, 41, 199-219.

Nixon, S.W., Granger, S.L., Nowicki, B.L. (1995). An assessment of the annual mass balance of carbon, nitrogen, and phosphorus in Narragansett Bay.

Biogeochemistry, 31, 15-61.

Paerl, H.W. (1985). Enhancement of marine primary production by nitrogen-enriched acid rain. Nature, 315 (27), 747-749.

Paerl, H.W., \& Fogel, M.L. (1994). Isotopic characterization of atmospheric nitrogen inputs as sources of enhanced primary production in coastal Atlantic Ocean waters. Marine Biology, 119, 635-645.

Paerl, H.W. (1995). Coastal eutrophication in relation to atmospheric nitrogen deposition: current perspectives. Ophelia, 41, 237-259.

Paerl, H.W., \& Whitall, D.R. (1999). Anthropogenically-derived atmospheric nitrogen deposition, marine eutrophication and harmful algal bloom expansion: is there a link? Ambio, 28(4), 307-311.

Paerl, H.W. (2002). Connecting atmospheric nitrogen deposition to coastal eutrophication. Environmental Science and Technology, A, 323-326.

Peierls, B.L., \& Paerl, H.W. (1997). Bioavailability of atmospheric organic nitrogen deposition to coastal phytoplankton. Limnol. Oceanogr., 42, 1819-1823.

Prospero, J.M., Barret, K., Church, T., Detener, F., Duce, R.A., Galloway, J.N., Levy, H., Moody, J., \& Quinn, P. (1996). Atmospheric deposition of nutrients to the North Atlantic Basin. Biogeochemistry, 35, 27-73.

Pryor, S.C., \& Barthelmie, R.J. (2000). Particle dry deposition to water surfaces: processes and consequences. Marine Pollution Bulletin, 41 (1-6), 220-231. 
Psuty, N.P., DeLuca, M.P., Lathrop, R., Able, K.W., Whitney, S., \& Grassle, J.F. (1993). The Mullica River-Great Bay National Estuarine Research Reserve: a unique opportunity for research, preservation, and management. Proceedings of Coastal Zone '93, July 1993. New Orleans, Louisiana: American Shore and Beach Preservation Association/ASCE, p. 1557-1568.

Rabalais, N.N. (2002). Nitrogen in aquatic ecosystems. Ambio, 31(2), 102-111.

Russell, K.M., Galloway, J.N., Macko, S.A., Moody, J.L., \& Scudlark, J.R. (1998).

Sources of nitrogen in wet deposition to the Chesapeake Bay region. Atmospheric Environment, 32 (14/15), 2453-2465.

Ryther, J.H., \& Dunstan, W.M. (1971). Nitrogen, phosphorous, and eutrophication in the coastal marine environment. Science, 171, 1008-1013.

Scudlark, J.R., Russell, K.M., Galloway, J.N., Church, T.M., \& Keene, W.C. (1998). Organic nitrogen in precipitation at the Mid-Atlantic U.S. coast - methods evaluation and preliminary measurements. Atmospheric Environment, 32 (10), 1719-1728.

Seinfeld, J.H., \& Pandis, S.N. (1998). Atmospheric Chemistry and Physics. John Wiley and Sons, Inc., New York.

Seitzinger, S.P., \& Sanders, R.W. (1999). Atmospheric inputs of dissolved organic nitrogen stimulate estuarine bacteria and phytoplankton. Limnol. Oceanogr., 44, 721-730.

Sheeder, S.A., Lynch, J.A., \& Grimm, J. (2002). Modeling atmospheric nitrogen deposition and transport in the Chesapeake Bay watershed. Journal of Environmental Quality, 31, 1194-1206.

Slinn, S.A., \& Slinn, W.G.N. (1980). Predictions for particle deposition on natural waters. Atmospheric Environment, 14, 1013-1016.

Valiela, I., Collins, G., Kremer, J., Lajtha, K., Geist, M., Seely, B., Brawley, J., \& Sham, C.H. (1997). Nitrogen loading from coastal watersheds to receiving estuaries: new method and application. Ecological Applications, 7(2), 358-380.

Valigura, R.A., Luke, W.T., Artz, R.S., \& Hicks, B.B. (1996). Atmospheric nutrient input to coastal areas: reducing the uncertainties. Decision analysis series no 9. Coastal ocean program, Silver Spring, MD: National Oceanic and Atmospheric Administration.

Vitousek, P.M., \& Howarth, R.W. (1991). Nitrogen limitation on land and in the sea: How can it occur? Biogeochemistry, 13, 87-115. 
Whitall, D., Hendrickson, B., \& Paerl, H. (2003). Importance of atmospherically deposited nitrogen to the annual nitrogen budget of the Neuse River estuary, North Carolina. Environment International, 29, 393-399.

Zampella, R.A., Bunnell, J.F., Laidig, K.J., \& Dow, C.L. (2001). The Mullica River Basin: A Report to the Pinelands Commission on the Status of the Landscape and Selected Aquatic and Wetland Resources. Technical Report. New Lisbon, New Jersey: Pinelands Commission, pp. 371. 
Table 1. Comparison of nitrate and ammonium concentrations in precipitation and in aerosols.

\begin{tabular}{|c|c|c|c|c|c|}
\hline Region & $\begin{array}{c}\text { Collection } \\
\text { Year }\end{array}$ & $\begin{array}{c}\mathrm{NO}_{3}^{-1} \\
\text { Precipitation } \\
\text { Concentration } \\
\left(\mathrm{mg} \mathrm{L}^{-1}\right) \\
\end{array}$ & $\begin{array}{c}\mathrm{NH}_{4}^{+} \\
\text {Precipitation } \\
\text { Concentration } \\
\left(\mathrm{mg} \mathrm{L}^{-1}\right) \\
\end{array}$ & $\begin{array}{c}\mathrm{NO}_{3}^{-1} \\
\text { Aerosol } \\
\text { Concentration } \\
\left(\mathbf{u g ~ m}^{-3}\right) \\
\end{array}$ & $\begin{array}{c}\mathrm{NH}_{4}^{+} \\
\text {Aerosol } \\
\text { Concentration } \\
\left(\mathrm{ug} \mathrm{m}^{-3}\right) \\
\end{array}$ \\
\hline $\begin{array}{c}\text { Mullica } \\
\text { River-Great } \\
\text { Bay Estuary, } \\
\text { NJ }\end{array}$ & $\begin{array}{l}2004- \\
2005\end{array}$ & 2.33 & 0.42 & 3.66 & \\
\hline $\begin{array}{l}\text { Barnegat } \\
\text { Bay, NJ }\end{array}$ & $\begin{array}{l}1999- \\
2001^{a}\end{array}$ & 1.8 & 0.33 & & 0.50 \\
\hline $\begin{array}{l}\text { Edwin B. } \\
\text { Forsythe } \\
\text { National } \\
\text { Wildlife } \\
\text { Refuge, } \\
\text { Atlantic } \\
\text { County, NJ }\end{array}$ & $2004^{b}$ & 1.00 & 0.20 & - & - \\
\hline & $2005^{c}$ & 1.04 & 0.21 & - & - \\
\hline Crossing, NJ & $2004^{c}$ & 1.53 & 0.30 & 1.2 & 1.5 \\
\hline $\begin{array}{c}\text { Chesapeake } \\
\text { Bay }\end{array}$ & $\begin{array}{l}1993- \\
1994^{d}\end{array}$ & 1.3 & 0.24 & - & - \\
\hline Abington, CT & $\begin{array}{l}2000- \\
2005^{\mathrm{e}}\end{array}$ & - & - & 0.84 & 1.1 \\
\hline $\begin{array}{c}\text { Blackwater, } \\
\text { MD }\end{array}$ & $\begin{array}{l}2000- \\
2005^{\mathrm{e}}\end{array}$ & - & - & 1.3 & 1.7 \\
\hline
\end{tabular}

${ }^{\mathrm{a}} \mathrm{Gao}, 2002$

${ }^{\mathrm{b}} \mathrm{NADP} / \mathrm{NTN}$

${ }^{\mathrm{c}}$ CASTNET/NADP-NTN

${ }^{\mathrm{d}}$ Russell et al., 1998

${ }^{\mathrm{e}}$ CASTNET 
Table 2. Comparison of annual wet and dry nitrogen deposition rates for nitrate and ammonium.

\begin{tabular}{|c|c|c|c|c|c|}
\hline Region & $\begin{array}{c}\text { Collection } \\
\text { Year }\end{array}$ & $\begin{array}{c}\text { Wet Deposition } \\
\mathrm{NO}_{3}^{-1} \\
\left(\mathrm{~kg}-\mathrm{N} \mathrm{ha}{ }^{-2} \text { year }^{-1}\right) \\
\end{array}$ & $\begin{array}{c}\text { Wet Deposition } \\
\mathrm{NH}_{4}^{+} \\
\left(\mathrm{kg}^{+} \mathrm{N} \mathrm{ha}^{-2} \text { year }^{-1}\right) \\
\end{array}$ & $\begin{array}{c}\text { Dry Deposition } \\
\mathrm{NO}_{3}^{-1} \\
\left(\mathrm{~kg}^{-1} \mathrm{Na}^{-2} \text { year }^{-1}\right) \\
\end{array}$ & $\begin{array}{c}\text { Dry Deposition } \\
\mathrm{NH}_{4}^{+} \\
\left(\mathrm{kg}-\mathrm{N} \mathrm{ha}^{-2} \text { year }^{-1}\right) \\
\end{array}$ \\
\hline $\begin{array}{c}\text { Mullica } \\
\text { River-Great } \\
\text { Bay } \\
\text { Estuary, NJ }\end{array}$ & $\begin{array}{l}2004- \\
2005\end{array}$ & 6.21 & 3.77 & 0.874 & 0.670 \\
\hline $\begin{array}{l}\text { Washington } \\
\text { Crossing, } \\
\text { Mercer } \\
\text { County, NJ }\end{array}$ & $2004^{\mathrm{a}}$ & 4.0 & 3.23 & & 0.5 \\
\hline $\begin{array}{l}\text { Edwin B. } \\
\text { Forsythe } \\
\text { National } \\
\text { Wildlife } \\
\text { Refuge, } \\
\text { Atlantic } \\
\text { County, NJ }\end{array}$ & $2004^{b}$ & 9.66 & 2.22 & - & - \\
\hline $\begin{array}{l}\text { Wye, } \\
\text { Maryland }\end{array}$ & $1996^{c}$ & & - & 0.05 & - \\
\hline
\end{tabular}

${ }^{\text {a }}$ CASTNET/NADP-NTN

${ }^{\mathrm{b}} \mathrm{NADP} / \mathrm{NTN}$

${ }^{c}$ AIRMoN 
Table 3. Annual wet and dry deposition rates for nitrate and ammonium for the Mullica River-Great Bay Estuary from March 2004 to March 2005.

\begin{tabular}{cccc}
\hline & $\begin{array}{l}\text { Wet Deposition } \\
\left(\mathrm{kg}-\mathrm{N} \mathrm{ha} \mathrm{yr}^{-1}\right)\end{array}$ & $\begin{array}{c}\text { Dry Deposition } \\
\left(\mathrm{kg}-\mathrm{N} \mathrm{ha} \mathrm{yr}^{-1}\right)\end{array}$ & $\begin{array}{c}\text { Total Deposition } \\
\left(\mathrm{kg}-\mathrm{N} \mathrm{ha-2} \mathrm{yr}^{-1}\right)\end{array}$ \\
\hline $\mathrm{NO}_{3}{ }^{-}$ & $6.21(62 \%)$ & $0.87(56 \%)$ & $7.08(61 \%)$ \\
$\mathrm{NH}_{4}{ }^{+}$ & $3.77(38 \%)$ & $0.67(44 \%)$ & $4.44(39 \%)$ \\
\hline Total & $9.98(87 \%)$ & $1.54(13 \%)$ & 11.52
\end{tabular}




\section{Figure Captions}

Figure 1. Map of the Mullica River-Great Bay Estuary displaying the site of atmospheric sampling at the Rutgers University Marine Field Station (RUMFS). Inset shows location of the estuary with respect to the state of New Jersey (Kennish et al., 2004).

Figure 2. Concentrations of nitrate and ammonium in precipitation samples collected at RUMFS from March 2004 to March 2005.

Figure 3. Concentrations of aerosol nitrate and ammonium for samples collected at RUMFS from March to May 2004.

Figure 4. Relationship between $\mathrm{pH}$ and nitrate and ammonium concentrations in precipitation (March 2004 to March 2005).

Figure 5(a). Seasonal wet deposition of nitrate and ammonium at the RUMFS site from March 2004 to March 2005.

Figure 5(b). Monthly dry deposition of nitrate and ammonium for the spring of 2004 at the RUMFS site. 


\section{ACCEPTED MANUSCRIPT}

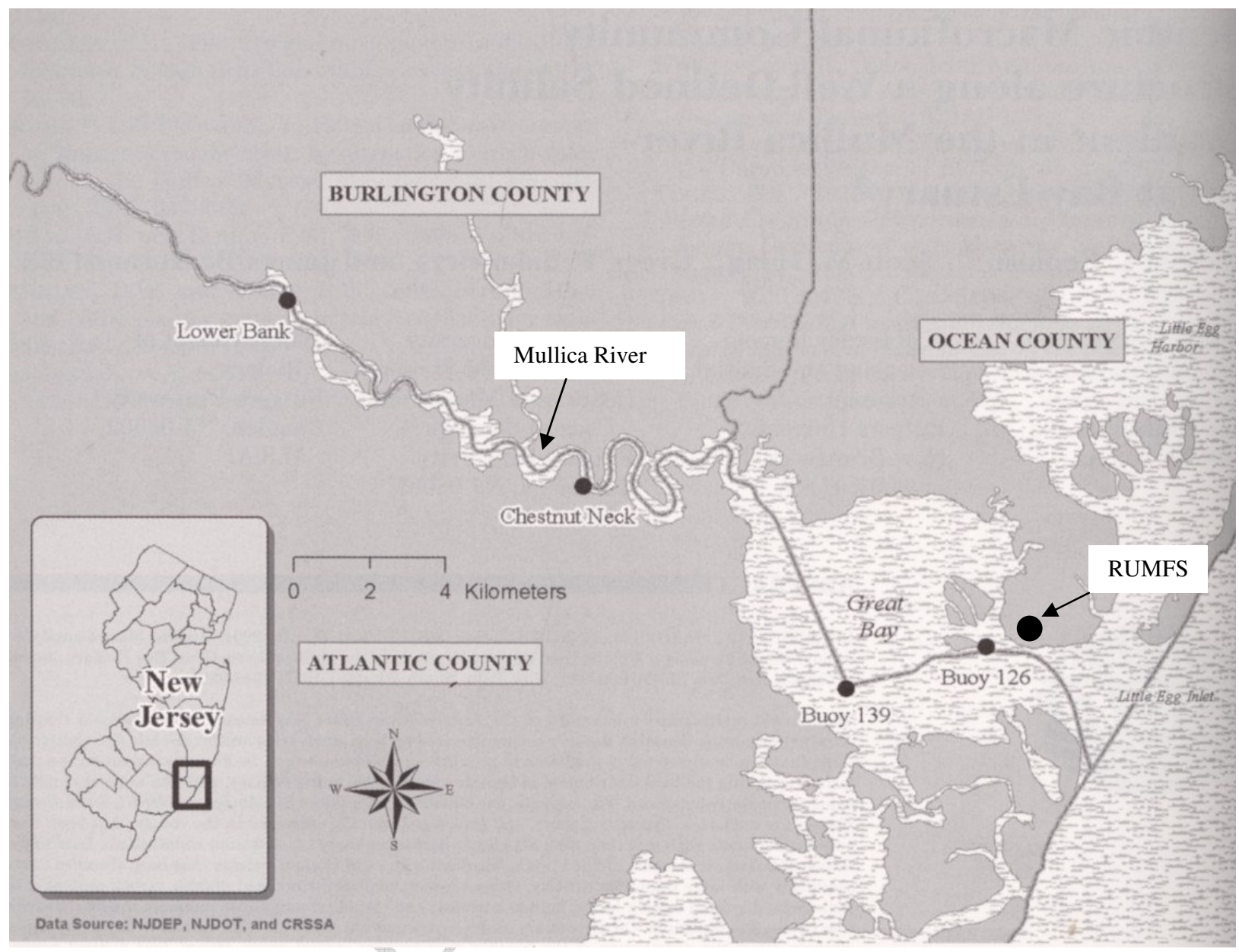

Figure 1 


\section{ACCEPTED MANUSCRIPT}

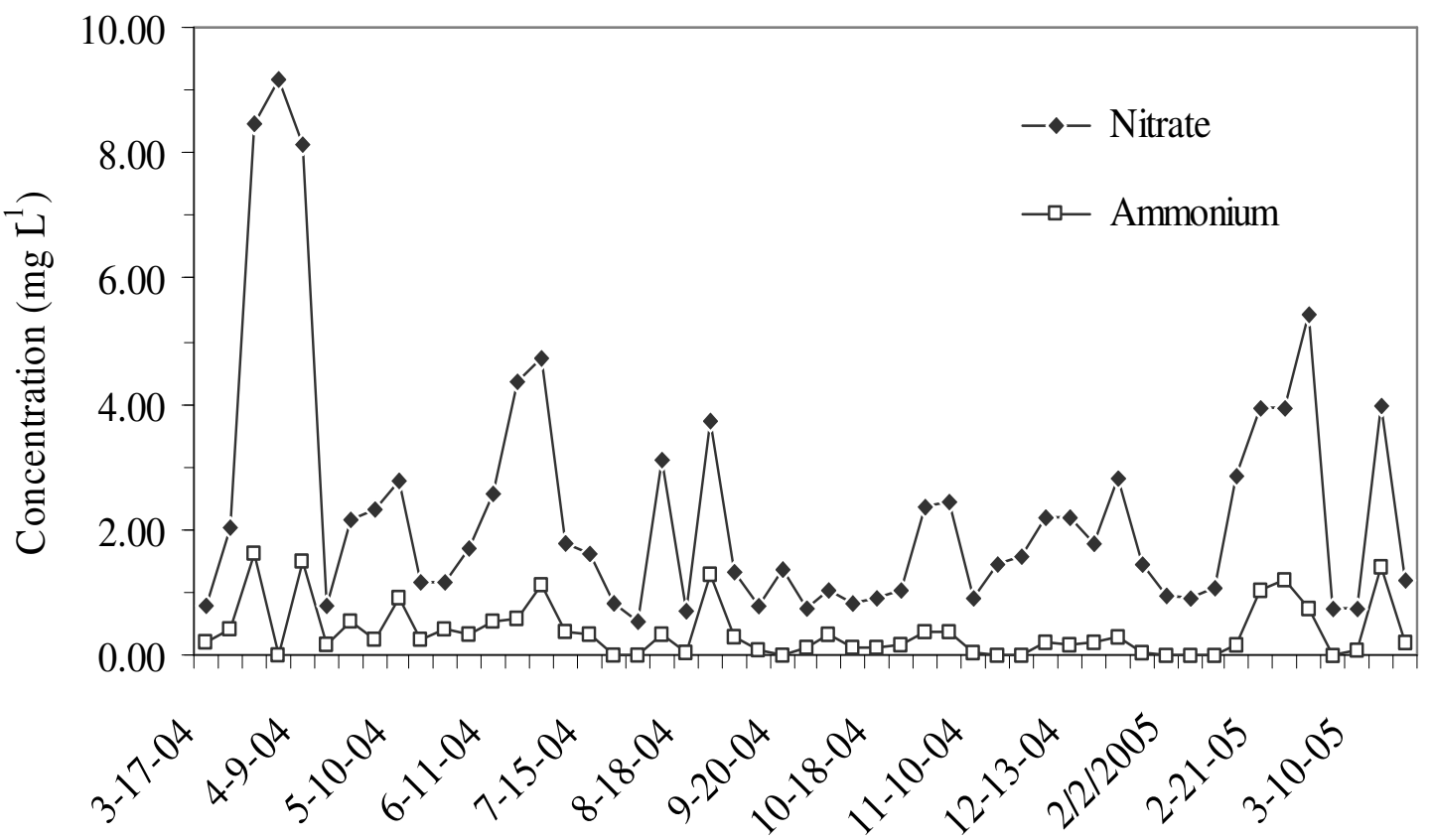

Date (2004-2005)

Figure 2 


\section{ACCEPTED MANUSCRIPT}

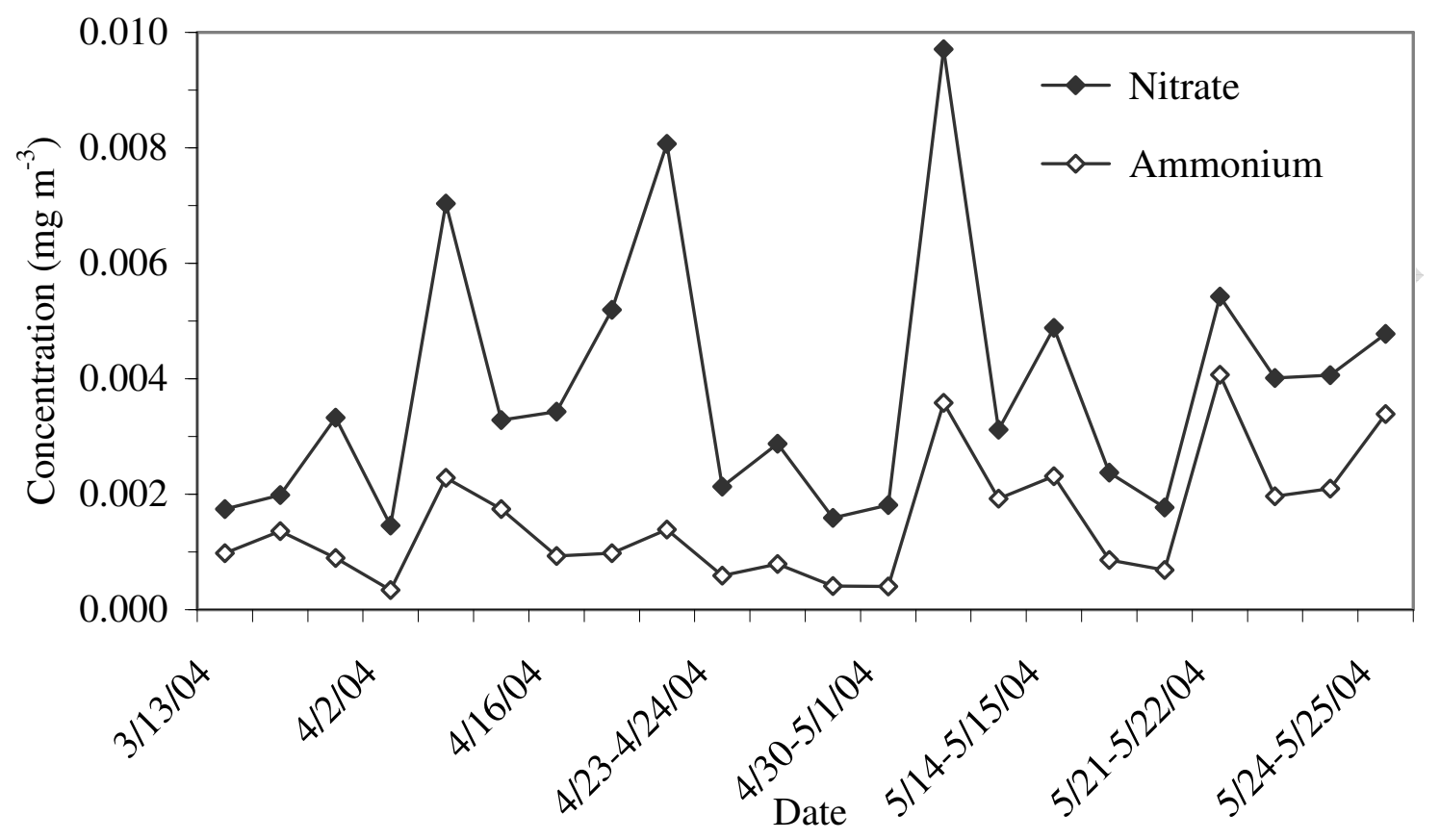

Figure 3 

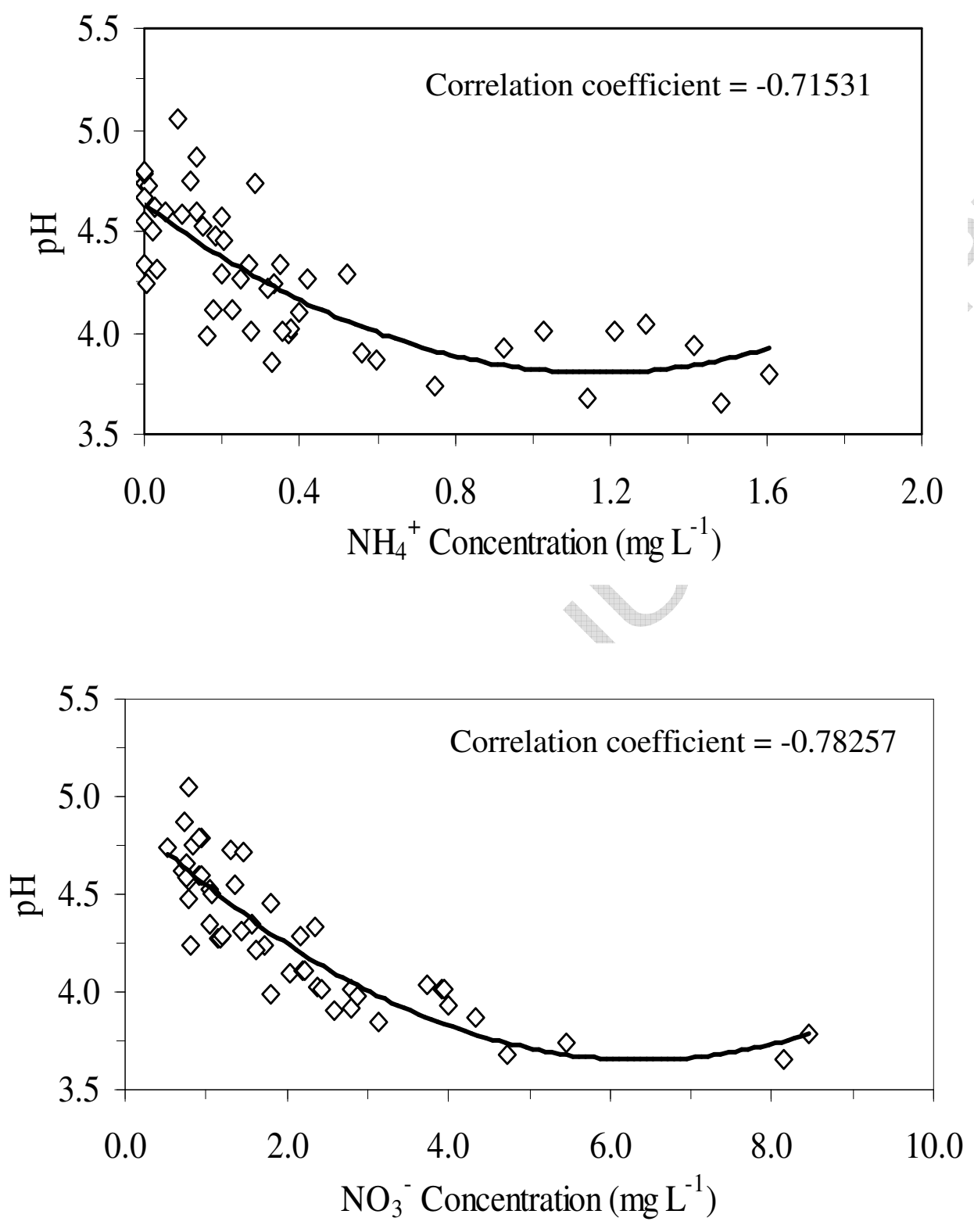

Figure 4 


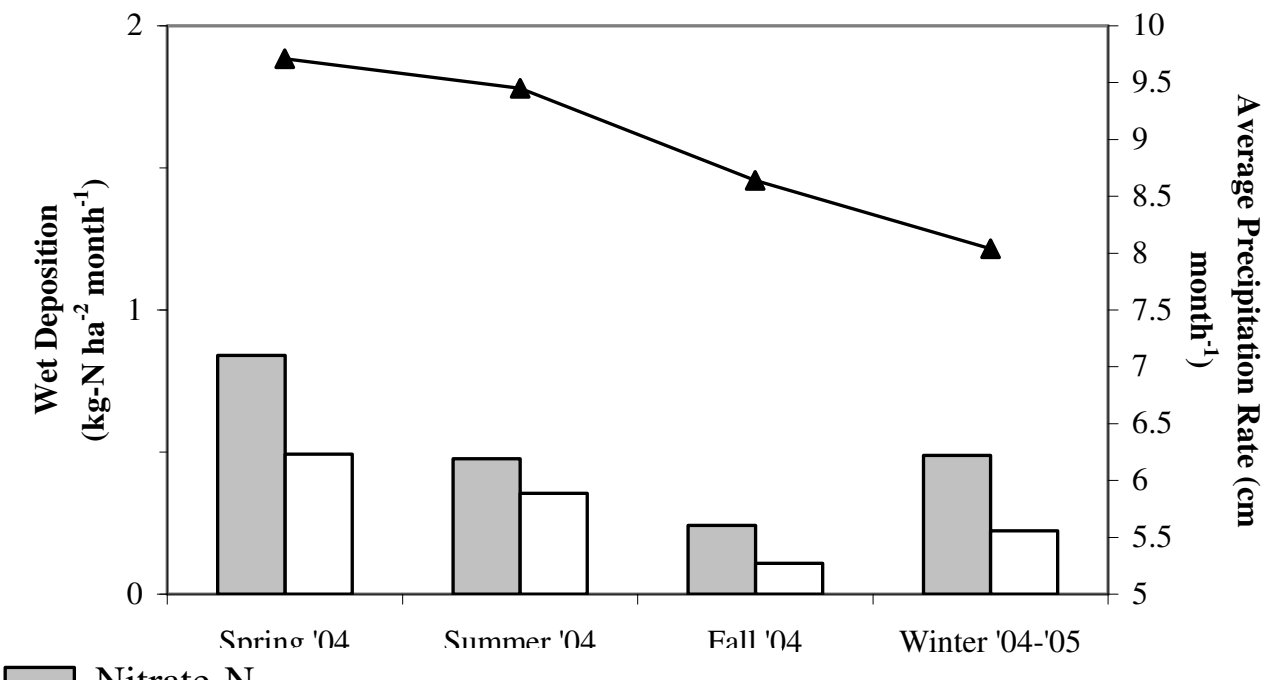

Nitrate-N

Ammonium-N

$\neg$ Average Precipitation Rate (cm month-1)

Figure 5(a)

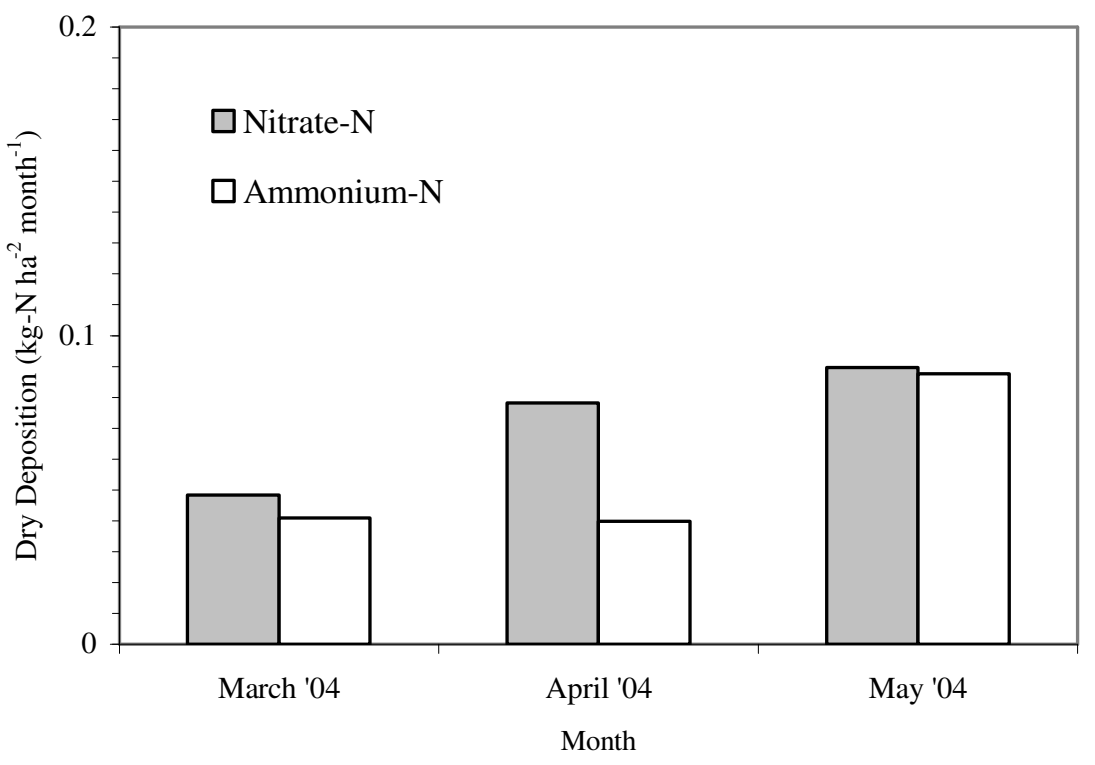

Figure 5(b) 